\title{
Post-Polio Syndrome
}

\section{Monalisa Pereira Motta ${ }^{1}, *$, Abrahão Augusto Juveniano Quadros ${ }^{1,2}$ Mônica de Souza Brito Conti ${ }^{1}$ and Acary Souza Bulle Oliveira ${ }^{1}$}

${ }^{1}$ Federal University of São Paulo (UNIFESP). Division of Neuromuscular Disorders. Department of Neurology and Neurosurgery. Rua Pedro de Toledo, 650. Vila Clementino. São Paulo-SP, Brazil (CEP 04039-002). *Email: mona_motta@yahoo.com.br.

${ }^{2}$ Neurologic Rehabilitation Service. Policlínica. Centro Universitário Adventista de São Paulo (UNASP). Estrada de Itapecerica, 5859. São Paulo-SP, Brazil (CEP 05858-001).

Abstract. Among the late effects of poliomyelitis is the PostPolio Syndrome (PPS), characterized by increased muscle strength loss, abnormal fatigue and pain after a period of stability of at least 15 years. The incidence and prevalence of PPS are unknown in the world and in Brazil, depending on the diagnostic criteria. The diagnosis of PPS is made by exclusion and there is no specific laboratory test, these only help to rule out other diseases. There is no curative treatment for PPS. Its etiology remains unknown. Strategies for their clinical management aim reducing muscle overusing and a balance active lifestyle is recommended to minimize the symptoms.

Keywords: Post-Poliomyelitis Syndrome; Neuromuscular disorders; Treatment; Management.
Received

December 24, 2018

Accepted

December 31, 2018

Released

December 31, 2018

Full Text Article

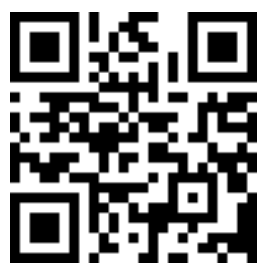

\footnotetext{
ORCID

(ㄷ) 0000-0003-2071-1216

Monalisa Pereira Motta

(๑) 0000-0001-8197-5915

Abrahão Augusto Juveniano Quadros

(c) 0000-0002-4810-7566

Mônica de Souza Brito Conti

D. 0000-0002-6986-4937

Acary Souza Bulle Oliveira
} 


\section{Introduction}

Post-Polio Syndrome (PPS) is a disorder of the nervous system characterized as a slow-onset disease with a generally insidious onset, manifesting in individuals who have had polio, with at least a 15-year period of stability after recovery from the acute episode of poliomyelitis. The mean interval between polio and the first manifestations is of approximately 35 years. (Neves et al., 2007; Conde et al., 2009; Oliveira and Quadros, 2009; Quadros et al., 2012). PPS can lead to deficiencies and disabilities which impose functional restrictions on everyday activities. The disease is characterized by the development of new neuromuscular symptoms, or worsening of previous residual symptoms, such as: muscular and progressive weakness, fatigue as well as pain in the muscles and joints (Oliveira and Quadros, 2009).

For many years, PPS was not considered well-defined clinical coding. Since October 2008, the World Health Organization (WHO) has recognized it as a distinct and incurable clinical disorder in its International Classification of Diseases (ICD) ICD10, with the inclusion of its own code: G14.0 (Quadros et al., 2012).

PPS is classified as a motor neuronopathy, as its clinical and histological aspects are closely related to lower motor neuron dysfunction (Oliveira and Maynard, 2002). The prevalence of PPS varies from 15\% to $80 \%$ among poliomyelitis survivors, depending on the diagnostic criteria applied and the population studied, and is therefore difficult to establish (Ramlow et al., 1992; Burger and Marincek, 2000). It is estimated that 70\% of the patients who have survived poliomyelitis will develop PPS. The new symptoms appear preferentially in previously affected limbs, as well as in patients with greater residual weakness (Oliveira and Maynard, 2002).

\section{Etiology}

Although the etiology of PPS is not fully understood, among the numerous hypotheses, the most accepted one is that it is not caused by new poliovirus activity, but by the overuse of surviving motor neurons over the years. This causes disintegration of the terminal axons and an intense metabolic demand (Oliveira and Maynard, 2002; Vranjac, 2006; Neves et al., 2007).

The PAA virus can damage up to $95 \%$ of the motor neurons of the anterior horn of the spinal cord, compromising at least $50 \%$ of them. With the damage to these neurons, the muscles in their activity area are left without innervation, causing paralysis and atrophy. The remaining neurons compensate for the damage by sending ramifications in order to reinnervate these denervated muscles. In this way, the neuromuscular function will be partially or totally recovered depending on the number of neurons involved in the reinnervation process (Vranjac, 2006; Neves et al., 2007).

Due to this neuronal compensation, a neuron will innervate a much larger number of fibers compared to what it would do under normal conditions. It thereby forms a giant motor unit, thus restoring motor function; even when more than $50 \%$ of motor neurons were injured and remain overloaded. When exposed to stress factors, e.g. super training, these surviving motor neurons may present physiological changes which reduce nerve conduction velocity. Additionally, they may exhibit early degeneration by, after years of functional stability, beginning to exhibit a new symptomatological set (Dalakas, 1995; Oliveira and Maynard, 2002; Vranjac, 2006; Neves et al., 2007).

Degeneration of the distal motor unit may also produce defects in neuromuscular transmission, which can cause muscle fatigue and gradual denervation of muscle fibers (due to the 
overload of motor units). This is the possible cause of the progressive muscle strength loss found in PPS (Trojan and Cashman, 2005). In addition, increased metabolic demand for a giant motor unit can lead to premature exhaustion and motor neuron death, resulting in muscle fatigue (Jubelt and Cashman, 1987).

\section{Risk factors}

To date, risk factors are unknown, but the possible factors for the development of PPS are: advanced age during the acute phase of the disease, female gender, severity of the initial motor condition, recent weight gain, major functional recovery, long latency period between the onset of the illness and recovery, increased physical activity, use of mechanical ventilation during the acute phase of the disease, hospitalization, acute polio at a late age, muscle pain associated with exercise and permanent deficiencies following recovery (Trojan et al., 1994; Khan, 2004; Neves et al., 2007; Oliveira and Quadros, 2009).

\section{Prevention}

To date, as its etiology is not known, there is no cure for PP. However, some measures can be taken to prevent the onset of the new symptoms that characterize PPS, or even to postpone them. As such, patients should:

- Observe primary health care by seeking periodic medical assistance;

- Carry out periodic medical checksups with a general practitioner and a doctor specializing in neuromuscular diseases, so that future changes can be observed, and a more appropriate treatment program can be developed, additionally making the early diagnosis of PPS possible;

- Maintain a healthy diet in order to avoid gaining excessive weight and eventual muscle and joint overload;

- Neither drink nor smoke;

- Pay attention to their own bodies;
- Perform regular physical activity, without overusing their muscles so as not to cause the exacerbation of symptoms such as pain and fatigue; - Avoid activity that can cause pain, as this is a warning sign from the body;

- Rest periodically whenever necessary (from 15 to 30 minutes);

- Use orthoses, molds, splints and other care devices carefully adjusted to the specifics of each patient. These are capable of preventing or delaying symptoms such as fatigue and pain. As is the use of crutches, walking sticks, wheelchairs and domestic adaptive instruments such as handrails/bars (Oliveira et al., 2004).

\section{Diagnosis}

The PPS diagnostic process is concentrated in a comprehensive clinical study where all other possible neurological, medical, orthopedic and psychological causes for further deterioration are discarded. There is no diagnostic test for PPS, and the diagnosis is based on clinical criteria (Oliveira and Maynard, 2002; Oliveira and Quadros, 2009).

Several authors have proposed diagnostic criteria for PPS (Halstead, 1991; Dalakas, 1995; Rowland et al., 2000). Currently, the most accepted criteria are those established by Halsted (1991) and Rowland et al. (2000). The reference center for the treatment of patients with poliomyelitis and PPS sequelae in Brazil (UNIFESP's Neuromuscular Diseases Sector) uses as diagnostic criteria a combination of the two most used, as described below:

- major paralytic poliomyelitis with evidence of motor neuron loss, as confirmed by a history of acute paralytic disease, signs of residual weakness and muscle atrophy upon neurological examination, and signs of denervation on electromyography (Halstead, 1991; Rowland et al., 2000); 
- partial or complete neurological and functional recovery after the acute episode of poliomyelitis (Halstead, 1991; Rowland et al., 2000);

- minimum period of 15 years of neurological and functional stability (Rowland et al., 2000; Halstead, 1991);

- gradual or abrupt onset of new muscle weakness, with or without other co-existing symptoms (Halstead, 1991);

- no other medical condition justifying the symptoms (Rowland et al., 2000; Halstead, 1991);

- the symptoms should persist for at least one year, illustrating the chronic course (Rowland et al., 2000).

\section{Clinical profile}

Clinically, the patients exhibit varied combination of musculoskeletal symptoms and progressive post-polio muscular atrophy (PPMA). The most common symptoms are: 1) increased muscle weakness; 2) fatigue; 3) muscle and joint pain; 4) new difficulties in carrying out everyday activities, particularly tasks related to mobility. Other symptoms include: 1) intolerance to cold; 2) respiratory dysfunction; 3) sleep disorders; 4) dysphagia; 5) speech difficulties (Oliveira and Maynard, 2002).

The new symptoms appear preferentially in previously affected limbs, and in patients with greater residual weakness (Oliveira and Maynard, 2002). These develop gradually over time, though may be sudden in cases with periods of inactivity, trauma, surgery or after vigorous activity (Rowland et al., 2000).

The rate of decline varies from patient to patient, and is usually quite slow and, even so, varying between patients. Long periods of stabilization followed by no clinical decline are not uncommon. (Oliveira and Maynard, 2002)
The appearance of new symptoms may be psychologically devastating. Trepidation is marked when these individuals predict their future physical condition and abilities - loss of independence, finances, physical abilities, and employment. These individuals who have been successful in trying to be normal over the years by hiding their physical limitations, now experience new symptoms and have to face the reality that they can no longer hide these limitations (Oliveira and Quadros, 2009).

\section{Treatment}

To date, there is no cure for PPS, however limiting symptoms can be controlled quite well.

A series of clinical studies were conducted between 1995 and 2017, testing the use of various drugs on the symptoms exhibited by patients with PPS, however their results were neither satisfactory nor conclusive. Among the drugs evaluated were Pyridostigmine (Trojan and Cashman, 1995; Trojan et al., 1999; Horemans et al., 2003), Modafinil (Chan et al., 2006; Vasconcelos et al., 2007), Amantadine (Stein et al., 1995) Bromocriptine (Bruno et al., 1996); (Dinsmore et al., 1995), Lamotrigine (On et al., 2005), intravenous immunoglobulin (Farbu et al., 2007), prednisone coupled with aminodine (Peel et al., 2015) and L-carnitine in conjunction with piracetam (Motta, 2017). However, few studies have demonstrated motor stabilization or functional recovery.

A clinical trial with acetylcholinesterase inhibitors aimed to reduce the development of fatigue in patients with PPS (Trojan and Cashman, 1995), observing improvement in muscular fatigue in seven patients among the 17 participants. This suggests that the peripheral mechanisms, in the case neuromuscular junction transmission defects, may underlie fatigue in a percentage of patients with PPS (Trojan 
and Cashman, 1995). However, a doubleblind, multicenter study, which was randomized and placebo-controlled, was conducted on 126 patients with PPS and showed no significant difference between the acetylcholinesterase inhibitor (pyridostigmine) and the placebo in terms of quality of life, isometric strength, fatigue, and IGF-1 serum levels (Trojan et al., 1999). In a separate single-center, randomized and placebo-controlled, double-blind study of pyridostigmine on 67 patients with PPS, there was no significant difference between patients using active medication and those using placebos, in relation to changes in fatigue, isometric resistance of the quadriceps and neuromuscular junction defects. There was only a small improvement in ambulation performance (Nollet et al., 2002). As such, more comprehensive studies have not shown the definitive benefit of pirisdostigmine, in fact presenting evidence that it is not effective in managing fatigue and muscle weakness in PPS.

Lamotrigine (50-100 $\mathrm{mg} /$ day) was given to 15 patients for four weeks, in conjunction with in-home exercises (individualized isometric and progressive resistance) as well as counseling (weight loss, orthoses, energy conservation), proving to temporarily relieve fatigue and improve the quality of life (On et al., 2005). However, the use of lamotrigine being effective against fatigue in patients with PPS can not be attributed to these results because, in addition to the sample being small, other strategies with beneficial effects regarding the symptom were adopted.

A small placebo-controlled clinical study was performed on five patients with PPS, using Bromocriptine as the active agent. There was a decrease in fatigue in three of the five patients (Bruno et al., 1996). However, studies with larger populations are needed in order to prove the efficacy of the drug on the symptoms.
Gonzales et al. (2004) found that intravenous immunoglobulin reduced the levels of inflammatory cytokines in the cerebral-spinal fluid of patients with PPS. In this way, attempts to use intravenous immunoglobulin as drug therapy in patients with PPS came to be questioned, followed by three relevant studies: Gonzalez et al. (2006) observed a significant difference in muscular strength among their 135 patients treated either with placebos or with $90 \mathrm{mg}$ of Ivlg, however, there was no benefit regarding quality of life, pain, balance and quality of sleep; Kaponides et al. (2006) conducted a 14-patient study with $90 \mathrm{mg}$ (30 g daily for 3 days) of Ivlg intravenous immunoglobulin on muscle strength, quality of life and physical ability. Positive results were noted in relation to quality of life, but not regarding muscular strength and physical capacity. Farbu et al. (2010) performed a 20-patient study with an Ivlg dosage of $2 \mathrm{~g} / \mathrm{kg}$ of body weight. Significant effects on pain were found, though not on muscle strength and fatigue. Treatment with intravenous immunoglobulin is indeed promising, however, more studies with larger populations need to be performed to prove its benefit. It should not be disregarded, however, that its cost is higher, and its adverse effects can be serious, the most common reactions being headache, chills, muscle pain and back pain (Farbu et al., 2010; Dalakas, 2004).

A randomized clinical trial evaluated the action of $330 \mathrm{mg}$ of L-carnitine in conjunction with $270 \mathrm{mg}$ of piracetam (twice a day) in the treatment of fatigue and muscle weakness in 94 patients with PPS. The patients were evaluated over 180 days. Force was evaluated using the Medical Research Council Manual Muscular Test instrument. Fatigue was evaluated using the Severity and Fatigue Scale and Piper's Revised Fatigue Scale. The study found improvement in fatigue and muscle strength, as compared with a 
placebo, and a decrease in muscle strength in the patients who took the medication. The association of these two drugs has been shown to be effective in managing fatigue and muscle weakness in this population (Motta, 2017).

Even today, the primary treatment for PPS is based on nonpharmacological interventions, lifestyle changes, physical therapy, training programs and the prevention of secondary complications.

Despite the research in the literature, a greater number of randomized, double-blind clinical trials with a larger number of patients, as well as longer periods of drug use, are needed to better predict the effects of drugs on this population, making new medicational strategies viable.

The deficiencies caused by the emergence of new symptoms, coupled with the primary deficiencies caused by the poliomyelitis, result in great restrictions. Therapeutic intervention in PPS aims to provide patients with selfcare principles and methods, making changes in lifestyle and reducing metabolic overload on motor neurons. The therapeutic approaches adopted should recommend the use of energy conservation techniques, as well as guidelines regarding regular rest periods, weight loss and the practice of exercises at levels that avoid excessive use. Additionally, the use of orthoses should be recommended when necessary (Orsini et al., 2008).

Appropriately supervised and moderate muscle training at aerobic levels is useful for maintaining muscle function and improving fatigue (Agre et al., 1997). It is essential that these exercises relieve symptoms without causing more weakness and fatigue in damaged muscles. For regular exercise, patients should also take regular breaks (Howard, 2005).

Inactivity increases the risk of obesity, diabetes, cardiovascular and musculoskeletal problems (Rekand et al., 2004), in addition to being a risk factor for the development of PPS (in cases of patients with only the sequelae of poliomyelitis). Additional weight contributes to impaired mobility, the development of osteoarthrosis, respiratory failure due to hypoventilation, and obstructive sleep apnea. The increase in body weight also reduces resistance and increases fatigue (Howard, 2005; Rosa et al., 2006). Weight loss is commonly difficult to achieve due to reduced mobility.

The primary goal of PPS treatment is to prevent subsequent deterioration by balancing activity and rest (Orsini et al., 2011).

\section{Conclusion}

It is extremely important that health professionals be well informed regarding PPS, such as related to possible causes and diagnostic criteria, as well as the process and evolution of the disease. A thorough evaluation of patient complaints can shorten the diagnosis time and enable early specific treatment, as well as prevent the onset of PPS.

This population must now be helped to accept and deal with the new limitations and symptoms that the PPS has brought about. The care of said population by an interdisciplinary team is important because, as such, more therapeutic resources will be made available for the common good of these patients.

\section{Conflicts of interest}

Authors declare that they have no conflict of interests.

\section{References}

Agre, J. C.; Rodriquez, A. A.; Franke, T. M. Strength, endurance, and work capacity after muscle strengthening exercise in postpolio subjects. Archives of Physical Medicine \& Rehabilitation, v.78, no. 7, p. 681-686, 1997. Available from: <https://www. 
archives-pmr.org/article/S0003-9993(97) 90073-3/pdf>. Accessed on: Apr. 23, 2018.

Burger, H.; Marincek, C. The influence of PostPolio Syndrome on independence and life satisfaction. Disability and Rehabilitation, v. 22 , no. 7, p. 318-322, 2000.

Bruno, R. L.; Zimmerman, J. R.; Creange, S. J.; Lewis, T.; Molzen, T.; Frick, N. M. Bromocriptine in the treatment of post-polio fatigue: A pilot study with implications for the pathophysiology of fatigue. American Journal of Physical Medicine \& Rehabilitation, v. 75 , no. 5, p. 340-347, 1996.

Conde, M. T. R. P.; Oliveira, A. S. B.; Quadros, A. A. J.; Moreira, G. A.; Silva, H. C. A.; Pereira, R. D. B.; Silva, T. M.; Tufik, S.; Waldman, E. A. Post-Polio Syndrome: Epidemiologic and prognostic aspects in Brazil. Acta Neurologica Scandinavica, v. 120, p. 191197, 2009. https://doi.org/10.1111/j.16000404.2008.01142.x

Chan, K. M.; Strohschein, F. J.; Rydz, D.; Allidina, A.; Shuaib, A.; Westbury, C. F. Randomized controlled trial of Modafinil for the treatment of fatigue in postpolio patients. Muscle Nerve, v. 33, p, 138-141, 2006. https://doi.org/10.1002/mus.20437

Dalakas, M. C. Intravenous immuneglobulin in autoimmune neuromuscular diseases. JAMA, v. 291, no. 19, p. 2367-2375, 2004. https://doi.org/10.1001/jama.291. 19.2367

Dalakas, M. C. The Post-polio syndrome as an evolved clinical entity: Definition and clinical description. Annals of the New York Academy of Sciences, v. 753, p. 68-80, 1995. https://doi.org/10.1111/j.1749-6632.1995. tb27532.x

Dinsmore, S.; Dambrosia, J.; Dalakas, M. C. A double-blind, placebo-controlled trial of highdose prednisone for the treatment of PostPoliomyelitis Syndrome. Annals of the New York Academy of Sciences, v. 753, p. 303313, 1995. https://doi.org/ 10.1111/j.17496632.1995.tb27556.x

Farbu, E. Update on current and emerging treatment options for Post-Polio Syndrome. Therapeutics and Clinical Risk Management, v. 6, p. 307-313, 2010. Available from: <https://www.ncbi.nlm.nih. gov/pmc/articles/PMC2909497/pdf/tcrm-6307.pdf>. Accessed on: Apr. 23, 2018.

Farbu, E.; Rekand, T.; Vik-Mo, E.; Lygren, H.; Gilhus, N. E.; Aarli, J. A. Post-Polio Syndrome patients treated with intravenous immunoglobulin: A double-blinded randomized controlled pilot study. European Journal of Neurology, v. 14, no. 1, p. 60-65, $2007 . \quad$ https://doi.org/ 10.1111/j.1468-1331.2006.01552.x

Gonzalez, H.; Khademi, M.; Andersson, M.; Piehl, F.; Wallström, E.; Borg, K.; Olsson, T. Prior poliomyelitis-IVIg treatment reduces proinflammatory cytokine production. Journal of Neuroimmunology, v. 150, n. $1 / 2$, p. $139-144$, 2004. https://doi.org/ 10.1016/j.jneuroim.2004.01.010

Gonzalez, H.; Sunnerhagen, K. S.; Sjoberg, I.; Kaponides, G.; Olsson, T.; Borg, K. Intravenous immunoglobulin for Post-Polio Syndrome: A randomised controlled trial. The Lancet, Neurology, v. 5, no. 6, p. 493500, 2006. https://doi.org/10.1016/S14744422(06)70447-1

Halstead, L. S. Assessment and differential diagnosis for Post-Polio Syndrome. Orthopedics, v. 14 , no. 11 , p. 1209-1217, 1991.

Horemans, H. L. D.; Nollet, F.; Beelen, A.; Drost, G.; Stegeman, D. F.; Zwarts, M. J.; Bussmann, J. B. J.; de Visser, M.; Lankhorst, G. J. Pyridostigmine in Postpolio Syndrome: No decline in fatigue and limited functional improvement. Journal of Neurology, Neurosurgery \& Psychiatry, v. 74, no. 12, p. 1655-1661, 2003. https://doi.org/ 10.1136/jnnp.74.12.1655

Howard, R. S. Poliomyelitis and the Postpolio Syndrome. BMJ, v. 330, p. 1-5, 2005. https://doi.org/10.1136/bmj.330.7503.1314 Jubelt, B.; Cashman, N. R. Neurological manifestations of the Post-Polio Syndrome. Critical Reviews in Neurobiology, v. 3, p. 199-220, 1987.

Khan, F. Rehabilitation for postpolio sequelae. Australian Family Physician, v. 33, no. 8, p. 621-624, 2004. Available from: <https://www.racgp.org.au/afpbackissues/2 004/200408/20040803khan.pdf>. Accessed on: Apr. 23, 2018.

Kaponides, G.; Gonzalez, H.; Olsson, T.; Borg, $\mathrm{K}$. Effect of intravenous immunoglobulin in patients with Post-Polio Syndrome: An uncontrolled pilot study. Journal of Rehabilitation Medicine, v. 38, no. 2, p. 138140, 2006. https://doi.org/10.1080/ 16501970500441625

Motta, M. P. Efeito terapêutico do uso da Lcarnitina+piracetam na fadiga e na força muscular de pacientes com Síndrome Pós- 
Poliomielite (SPP): estudo clínico randomizado, duplo-cego, controlado com placebo. São Paulo: Universidade Federal de São Paulo, Escola Paulista de Medicina, 2017. (Master thesis).

Neves, M. A. O.; Mello, M. P.; Reis, J. P. B.; Rei, A. M.; Antonioli, R. S.; Nascimento, O. J. M.; Freitas, M. R. G. A Síndrome Pós-Polio e o processo de reabilitação motora: relato de caso. Revista Neurociências, v. 15 , no. 4 , p.321-325, 2007. Available from: <http://www.revistaneurociencias.com.br/e dicoes/2007/RN 15 04/Pages from RN 15 04-13.pdf>. Accessed on: Apr. 23, 2018.

Nollet, F.; Horemans, H. L. D.; Beelen, A.; Drost, G.; Zwarts, M. J.; de Visser, M.; Lankhorst, G. J. Pyridostigmine in Postpolio Syndrome: A randomized double-blinded trial. Neurology, v. 58, no. 2, p. 199-200, 2002.

Oliveira, A. S. B.; Maynard, F. M. Síndrome Pós-Poliomielite: aspectos neurológicos Revista Neurociências, v. 10, no. 1, p. 31-34, 2002. Available from: <http://www.revista neurociencias.com.br/edicoes/2002/RN 10 01/RN 1001 5.pdf>. Accessed on: Apr. 23, 2018.

Oliveira, A. S. B.; Quadros, A. A. J. Síndrome Pós-Poliomielite: orientações para profissionais de saúde. São Paulo: SES/SP, 2008. (Versão para Internet). Available from: <http://www.saude.sp.gov.br/resources/ses /perfil/profissional-da-saude/homepage// sindrome_pos_poliomielite_pdf $>$. Accessed on: Apr. 23, 2018.

On, A. Y.; Oncu, J.; Uludag, B.; Ertekin, C. Effects of Lamotrigine on the symptoms and life qualities of patients with Post-Polio Syndrome: A randomized, controlled study. Neuro Rehabilitation, v. 20 , no. 4, p. 245251, 2005.

Orsini, M.; Mello, M. P.; Antonioli, R. S.; Nascimento, O. J. M.; Freitas, M. R. G. A Síndrome Pós-Pólio e o processo de reabilitação motora: relato de caso. Revista Neurociências, v. 15, p. 321-325, 2008. Available from: <http://www.revistaneuro ciencias.com.br/edicoes/2007/RN 15 04/Pages from RN 15 04-13.pdf>. Accessed on: Apr. 23, 2018.

Peel, M. M.; Cooke, M.; Lewis, H. J.; Lea, R. A.; Moyle, W. A randomized controlled trial of coenzyme Q10 for fatigue in the late-onset sequelae of poliomyelitis. Complementary Therapies in Medicine, v. 23, no. 6, p. 789-
793, 2015. https://doi.org/10.1016/ j.ctim.2015.09.002

Quadros, A. A. J.; Conde, M. T. R. P.; Marin, L. F.; Silva, H. C. A.; Mesquita e Silva, T.; Paula, M. B. E.; Pereira, R. D. B.; Ramos, P. E.; Abe, G.; Oliveira, A. S. B. Frequency and clinical manifestations of Post-Poliomyelitis Syndrome in a Brazilian tertiary care center. Arquivos de Neuro-Psiquiatria, v. 70, no. 8, p. 571-573, 2012 . https://doi.org/ 10.1590/S0004-282X2012000800002

Ramlow, J.; Alexander, M.; LaPorte, R.; Kaufmann, C.; Kuller, L. Epidemiology of the Post-Polio Syndrome. American Journal of Epidemiology, v. 136, no. 7, p. 769-786, 1992.

Rosa, L. N.; Cunha, M. C. B.; Franco, R. C. Qualidade de vida em indivíduos portadores da Síndrome Pós-Pólio. Arquivos Médicos do $\mathbf{A B C}$, v. 31, no. 1, p. 18-22, 2006. Available from: <https://www.portalnepas.org.br/ amabc/article/viewFile/230/226>. Accessed on: Apr. 23, 2018.

Rekand, T.; Korv, J.; Farbu, E.; Roose, M.; Gilhus, N. E.; Langeland, N.; Aarli, J. A.. Lifestyle and late effects after poliomyelitis. A risk factor study of two populations. Acta Neurologica Scandinavica, v. 109 , no. 2, p. 120-125, $2004 . \quad$ https://doi.org/ 10.1034/j.1600-0404.2003.00186.x

Rowland, L. P.; Bach, J. R.; Borg, K.; Cashman, N. R.; Dalakas, M. C.; Dean, E.; Halstead, L. S.; Headley, J. L.; John, T. J.; Johnston, R. B.; Olkin, R.; Perlman, S. L.; Trojan, D. A.; Vickrey, B. G.; Wendling, W. W. March of Dimes International Conference on Post-Polio Syndrome: Identifying best practices in diagnosis \& care. White Plains, NY: March of Dime, 2000. Available from: <https://www.polioplace.org/sites/default/f iles/files/MOD- Identifying.pdf>. Accessed on: Apr. 23, 2018.

Skough, K.; Krossén, C.; Heiwe, S.; Theorell, H.; Borg, K. Effects of resistance training in combination with coenzyme Q10 supplementation in patients with post-polio: A pilot study. Journal of Rehabilitation Medicine, v. 40, no. 9, p. 773-775, 2008. https://doi.org/10.2340/16501977-0245

Stein, D. P.; Dambrosia, J. M.; Dalakas, M. C. A double-blind, placebo-controlled trial of amantadine for the treatment of fatigue in patients with the Post-Polio Syndrome. Annals of the New York Academy of Sciences, v. 753, no. 1, p. 296-302, 1995. 
https://doi.org/10.1111/j.1749-6632.1995. tb27555.x

Trojan, D. A.; Cashman, N. R. An open trial of pyridostigmine in Post-Poliomyelitis Syndrome. Canadian Journal of Neurological Sciences, v. 22, no. 3, p. 223-227, 1995. https://doi.org/10.1017/ S0317167100039883

Trojan, D. A.; Cashman, N. R. PostPoliomyelitis Syndrome. Muscle Nerve, v. 31, no. 1, p. 6-19, 2005. https://doi.org/ 10.1002/mus.20259

Trojan, D. A.; Cashman, N. R.; Shapiro, S.; Tansey, C. M.; Esdaile, J. M. Predictive factors for Post-Poliomyelitis Syndrome. Archives of Physical Medicine and Rehabilitation, v. 75, p. 770-777, 1994. Available from: <https://www.archives-pmr.org/article/ 0003-9993(94)90134-1/pdf>. Accessed on: Apr. 23, 2018.

Trojan, D. A.; Collet, J.-P.; Shapiro, S.; Jubelt, B.; Miller, R. G.; Agre, J. C.; Munsat, T. L.; Hollander, D.; Tandan, R.; Granger, C.; Robinson, A.; Finch, L.; Ducruet, T.; Cashman, N. R. A multicenter, randomized, doubleblinded trial of pyridostigmine in Postpolio Syndrome. Neurology, v. 53, no. 6, p. 12251233, 1999. https://doi.org/10.1212/ WNL.53.6.122
Vasconcelos, O. M.; Prokhorenko, O. A.; Salajegheh, M. K.; Kelley, K. F.; Livornese, K.; Olsen, C. H.; Vo, A. H.; Dalakas, M. C.; Halstead, L. S.; Jabbari, B.; Campbell, W. W. Modafinil for treatment of fatigue in Post-Polio Syndrome: A randomized controlled trial. Neurology, v. 68, no. 20, p. 1680-1686, 2007. https://doi.org/10.1212/01.wnl.000026191 2.53959.b4 